\title{
GAMIFIKASI DAN KORELASINYA DENGAN MINAT MENGUNJUNGI ULANG PADA MARKETPLACE " $X$ "
}

\author{
Bimo Wicaksono ${ }^{1}$, Fransiska Anita Subari ${ }^{2}$ \\ ${ }^{1}$ Pegawai Swasta, Bandung \\ ${ }^{1,2}$ Program Studi Administrasi Bisnis, Universitas Katolik Parahyangan, Bandung \\ 1bimowcksno@gmail.com \\ ${ }^{2}$ fransiskaanita@unpar.ac.id
}

\begin{abstract}
ABSTRAK
Bagaimana orang-orang menikmati permainan, khususnya permainan daring, dilihat sebagai sebuah kesempatan untuk menarik minat pengunjung, dalam hal ini pengunjung marketplace. Berbeda dengan toko offline di mana, traffic pengunjung dapat ditingkatkan melalui berbagai gimmik, event dan lain sebagainya. Salah satu upaya yang dapat dilakukan marketplace untuk meningkatkan traffic pengunjung adalah melalui penyediaan layanan permainan daring. Sifat permainan yang menyenangkan, addictive, membuat para pelaku pasar mulai memasukkan unsur permainan ke dalam sebuah usaha yang dikenal sebagai gamifikasi. Marketplace $\mathrm{X}$ merupakan salah satu marketplace yang menyediakan layanan permainan gamifikasi. Dengan pengunjung berulang kali mengakses permainan diharapkan usaha pemasaran marketplace $\mathrm{X}$ dapat terekspos kepada pengguna. Penelitian ini bermaksud untuk mengetahui apakah terdapat hubungan antara gamifikasi dengan minat mengunjungi ulang marketplace X. Penelitian ini menggunakan metode penelitian kuantitatif didukung dengan alat bantu pengolahan data SPSS. Teknik pengumpulan data menggunakan teknik purposive sampling yang mana responden adalah mereka yang pernah bermain gamifikasi di marketpace $\mathrm{X}$ dan berdomisili di Kota Bandung. Hasil temuan menunjukkan gamifikasi yang ditawarkan oleh Marketplace X dinilai baik oleh responden dan responden memiliki niat mengunjungi ulang yang tinggi untuk mengunjungi kembali marketplace $\mathrm{X}$ di waktu mendatang. Di samping itu, terdapat korelasi yang cukup kuat antara gamifikasi dan minat mengunjungi ulang. Oleh sebab itu, Marketplace X perlu mengelola dengan baik gamifikasi yang dimilikinya agar dapat menarik minat mengunjungi ulang yang merupakan salah satu cara untuk memasarkan produknya.
\end{abstract}

Kata Kunci: gamifikasi, online games, marketplace, minat mengunjungi ulang

\begin{abstract}
How people enjoy games, especially online games, is seen as an opportunity to attract visitors, in this case marketplace visitors. In contrast to offline stores where visitor traffic can be increased through various gimmicks, events, and so on. One of the efforts that the marketplace can make to increase visitor traffic is through the provision of online game services. The fun, addictive nature of the game has made market participants interested in incorporating game elements into a business that is not related to games. This became known as gamification. Marketplace X is one of the marketplaces that provides gamification game services. With repeated visitors accessing the gamification, it is hoped that the marketing efforts of Marketplace $X$ will be exposed to users. This study intends to determine whether there is a relationship between gamification and the interest in revisiting the marketplace. This study uses quantitative research methods supported by SPSS data processing tools to test hypotheses. The data collection technique uses a purposive sampling technique in which the respondents are those who have played gamification in marketplace $X$ and are domiciled in the city of Bandung. The results show that the gamification offered by Marketplace $X$ is considered good by respondents and respondents have a high intention to revisit the marketplace in the future. In addition, there is a fairly strong correlation between gamification and re-visit intention. Therefore, Marketplace $X$ needs to manage its gamification well to attract repeat visits, which is one way to marketing its products.
\end{abstract}

Keywords: gamification, online games, marketplace, re-visit intention

\section{PENDAHULUAN}

Berdasarkan data iprice (2018), diketahui terdapat 41 marketplace yang saling bersaing untuk memperoleh pangsa pasar Indonesia. Banyaknya jumlah marketplace di Indonesia menyebabkan konsumen dapat dengan mudah beralih dari satu marketplace ke marketplace lainnya. Hal ini menjadi tantangan yang cukup besar bagi pengelola marketplace untuk menjaga konsumennya tetap mengunjungi marketplace-nya dan tidak beralih ke tempat lain. Seperti halnya pasar offline (seperti mall), pasar online juga perlu memperhatikan jumlah orang yang mengunjungi toko tersebut atau biasa disebut traffic pengunjung. Dengan banyaknya traffic pengunjung, diharapkan 
promosi yang dilakukan dapat terkekspos kepada banyak orang. Jika mall menggunakan bioskop, restoran atau tempat bermain anak untuk menarik pengunjung datang, maka sebuah marketplace harus menggunakan strategi lain agar dapat mengundang pengunjung untuk mengakses situs toko tersebut.

Marketplace X dapat dikatakan sebagai salah satu leader di Indonesia dimana beragam vendor (toko online) berkumpul dan memasarkan produk mereka. Saat ini marketplace $\mathrm{X}$ menggunakan gamifikasi sebagai salah satu strategi agar orang-orang mau mengunjungi situs tersebut. Tidak hanya sekali, sifat permainan yang addictive diharapkan dapat membuat pengunjung bersedia mengakses berulang kali sebuah marketplace.

Gamifikasi adalah penerapan elemenelemen game ke dalam konteks non game (Deterding, Dixon, Khaled, \& Nacke , 2011). Menurut Silviani \& Cipto (2018), game dapat menarik perhatian banyak orang karena dianggap sebagai suatu kegiatan yang menyenangkan melalui pencapaian point, rank, reward, dan leaderboard.

Gamifikasi dalam sebuah marketplace harus dilakukan dengan hati-hati, mengingat bahwa tujuan dimasukkannya unsur permainan adalah bukan hanya membuat pengunjung menikmati perasaan senang ketika bermain, tetapi juga membuat mereka tereksplorasi atau memperhatikan usaha-usaha pemasaran lain yang dilakukan oleh marketplace tersebut, seperti potongan harga, harga khusus, voucher, atau event khusus seperti harbolnas. Untuk itu unsur permainan yang ada dalam sebuah marketplace hendaknya menarik, menyenangkan, tetapi juga tetap memberikan ruang yang luas untuk memperhatikan kegiatan pemasaran lain yang dilakukan oleh marketplace tersebut.

Seperti pada online games umumnya, gamifikasi juga menerapkan aspek-aspek pencapaian level dan reward (Hamari, Koivisto, \& Sarsa, 2014). Beberapa permainan harus melibatkan orang lain untuk mencapai reward tertentu. Perlu diingat, bahwa para pemain pada sebuah marketplace bukanlah game player yang sesungguhnya. Mereka berasal dari beragam segmentasi pasar yang mungkin bermain hanya untuk mengisi waktu luang. Perasaan senang ketika bermain dan mengetahui ada orang lain yang dikenal juga memainkan permainan yang sama, tampilan permainan, kemudahan memainkan dan didorong dengan reward bisa membuat seseorang tertarik untuk bermain berulang kali.

Penelitian ini berfokus pada pengukuran gamifikasi yang dilihat dari dimensi motivasi dan keterlibatan yang merupakan salah satu faktor di dalam gamifikasi (Broer \& Poeppelbuss, 2013). Selain itu, akan dilihat pula hubungan dan pengaruh gamifikasi terhadap keinginan untuk mengunjungi ulang.

\section{KAJIAN TEORI}

\section{Gamifikasi}

Pada dasarnya, gamifikasi adalah penerapan elemen game yang dapat berupa produk, cara berpikir, proses, pengalaman, cara desain, dan system untuk menyelesaikan masalah non game ke dalam kehidupan nyata (real-life environment) (Marisa, Akhriza, Maukar, \& Wardhani, 2020; Kankanamge, Yigitcanlar, Goonetilleke, \& Kamruzzaman, 2020). Gamifikasi mulai dikenal sejak tahun 2011 yang merupakan salah satu metode untuk memotivasi keterlibatan komunitas dalam berbagai tindakan. Gamifikasi bertujuan untuk melibatkan individu ke dalam kegiatan yang menyerupai kehidupan nyata yang lebih menyenangkan daripada yang seharusnya. Istilah gamifikasi digunakan untuk menunjukkan permainan persuasive yang dapat memotivasi kesadaran dan keterlibatan masyarakat (Kankanamge, Yigitcanlar, Goonetilleke, \& Kamruzzaman, 2020). Gamifikasi dapat meningkatkan motivasi sehingga pemain termotivasi dan bersemangat untuk melakukan sesuatu (Marisa, Akhriza, Maukar, \& Wardhani, 2020). Penggunaan gamifikasi ini tidak terfokus pada satu bidang ilmu tertentu tapi dapat dipergunakan untuk meningkatkan motivasi dan keterlibatan dalam berbagai disiplin imu yang berbeda seperti perencanaan kota, kesehatan, perdagangan dan pemasaran, pendidikan, energi (Kankanamge, Yigitcanlar, Goonetilleke, \& Kamruzzaman, 2020). 
Gamifikasi juga dapat diterapkan di dalam bidang bisnis, seperti gamifikasi dapat membuat kinerja pegawai dengan menetapkan intranet organisasi untuk meningkatkan komunikasi dan kolaborasi, atau mengatur kompetisi penjualan dan papan skor secara real-time untuk meningkatkan pendapatan dan memotivasi staf untuk bekerja lebih efektif (Marisa, Akhriza, Maukar, \& Wardhani, 2020).

Gamification dimanfaatkan untuk tujuan bisnis dan untuk mempengaruhi perilaku pelanggan. Kontrol elemen game dalam gamifikasi dapat berdampak positif pada pengalaman bermain game dan pembentukan niat pelanggan. Misalnya, Alibaba telah menyiapkan mekanisme permainan di platform pembayarannya, di mana jumlah pohon yang ditanam tergantung pada proses individu dalam memenuhi tanggung jawab sosialnya, di lain sisi mekanisme permainan ini merangsang konsumen untuk melakukan pembelian (menimbulkan minat beli) (Xu, Chen, Peng, \& Anser, 2020).

Gamifikasi dapat meningkatkan keterlibatan pengguna (audience engagement) dan penggunaan berulang (repeat use). Penerapan gamifikasi dapat bermanfaat bagi bidang pemasaran dan pembelajaran (learning) (Pratomo, 2018). Hal ini mendasari dugaan bahwa gamifikasi juga dapat mempengaruhi keinginan seseorang untuk mengakses suatu situs secara berulang, dalam hal ini adalah marketplace.

Pada penelitian yang dilakukan oleh Broer dan Kumar, seperti dikutip oleh Marsudi (2018), keberhasilan gamifikasi diukur berdasarkan elemen-elemen permainan online pada umumnya, seperti poin, peringkat yang berwujud badge atau leaderboard, maupun pencapaian level tertentu dan dorongan yang diberikan agar pemain mau mencapai level tertentu.

Menurut Shang dan Lin (2013) , permainan adalah cara yang ampuh untuk mempengaruhi dan merubah perilaku penggunanya untuk tujuan apa pun, penggunaan gamifikasi dalam interaksi yang dilakukan pelanggan telah menjadi strategi lazim untuk memahami perilaku pelanggan, menjaga kepuasan pelanggan, dan meningkatkan loyalitas pelanggan.
Selain itu, gamifikasi bertujuan untuk memotivasi dan melibatkan penggunanya untuk memecahkan masalah atau mencapai suatu tujuan (Zichermann \& Linder, 2010; Broer \& Poeppelbuss, 2013). Dalam penelitian ini, variabel gamifikasi akan dilihat dari 2 dimensi utama yaitu motivasi dan keterlibatan. Lalu melihat korelasi gamifikasi dan minat mengunjungi ulang di marketplace.

\section{Motivasi dalam Mengikuti Gamifikasi}

Gamifikasi bertujuan untuk meningkatkan motivasi konsumen dan keterlibatan konsumen di dalam aktivitas gamifikasi dan menyediakan pengalaman yang baik sehingga dapat meningkatkan tingkat belanja konsumen (Xu, Chen, Peng, \& Anser, 2020).

Menurut Broer \& Poeppelbuss (2013), motivasi mengacu pada alasan mengapa seseorang melakukan aktivitas tertentu. Motivasi dapat dikategorikan ke dalam 2 kelompok yang berbeda yaitu motivasi ekstrinsik dan intrinsik. Motivasi instrinsik didefinisikan sebagai dorongan menjalankan aktivitas karena kepuasan aktivitas tersebut dan bukan karena konsekuensi yang terpisah. Sedangkan motivasi ekstrinsik adalah kebalikannya, yaitu sebagai dorongan menjalankan aktivitas dengan tujuan mendapatkan suatu imbalan terpisah (Deci \& Ryan, 200). Penggunaan motivasi ekstrinsik dan intrinsik di dalam gamifikasi merupakan cara yang umumnya digunakan untuk meningkatkan keterlibatan pengguna. Gamifikasi dapat meningkatkan motivasi intrinsik seperti kebersediaan untuk berpartisipasi, rasa penasaran, dan sebagainya. Sedangkan gamifikasi yang berasal dari motivasi ekstrinsik seperti badges, ranks, rewards, dan lain sebagainya (Kankanamge, Yigitcanlar, Goonetilleke, \& Kamruzzaman, 2020).

Hasil penelitian terdahulu yang dilakukan oleh Kankanamge, Yigitcanlar, Goonetilleke, \& Kamruzzaman (2020) menunjukkan bahwa pengelolaan motivasi intrinsik, motivasi ekstrinsik, dan keterlibatan pengguna dapat bermanfaat untuk memaksimalkan penggunaan aplikasi gamifikasi dalam penelitian, pendidikan dan intervensi lainnya. 
Mendukung penggunaan gamifikasi dalam aplikasi non-game, Shang \& Lin (2013) mengemukakan bahwa pemberian reward sebagai bentuk imbalan atas kunjungan dan pembelian yang rutin, membuat game yang unik dan interaktif, serta mengimplementasikan berbagai macam fitur interaktif dari desain game adalah cara-cara yang dapat dilakukan untuk memotivasi konsumen untuk mendapatkan minat pelanggan.

Gamifikasi di dalam marketplace perlu membangkitkan motivasi pengguna, salah satunya melalui pemberian manfaat bagi pengguna bila bermain atau berbelanja di marketplace tersebut. Misalnya, poin yang diperoleh dari hasil bermain dapat digunakan untuk membeli suatu produk dan lain sebagainya (Xu, Chen, Peng, \& Anser, 2020).

\section{Keterlibatan Konsumen (Consumer Engagement)}

Berdasarkan hasil studi konseptual, keterlibatan konsumen umumnya dianalisis dari berbagai sudut pandang (multidimensi) yang dapat berasal dari kombinasi aspek kognitif, emosional dan perilaku konsumen (Gatautis, et al., 2021). Keterlibatan konsumen adalah tingkat tertentu dari motivasi konsumen yang terkait dengan objek tertentu-perusahaan, produk/jasa, atau merek atau keadaan yang bergantung pada situasi tertentu yang dapat digambarkan sebagai aktivitas kognisi, emosi, atau perilaku dalam interaksi langsung dengan objek keterlibatan (Banytè, Kuvykaitè, \& Tarutè, 2021). Platform sosial, ruang virtual, situs web dan gamifikasi dapat menjadi objek untuk mengukur keterlibatan konsumen (Gatautis, et al., 2021).

Keterlibatan konsumen menjadi salah satu faktor pendukung terciptanya gamifikasi di dalam suatu perusahaan. Keterlibatan konsumen menunjukkan respon pengguna terhadap aktivitas gamifikasi yang umumnya menggunakan media elektronik seperti komputer, handphone dan lain sebagainya. Oleh sebab itu, gamifikasi yang baik, seharusnya mampu meningkatkan keterlibatan pengguna (Broer \& Poeppelbuss, 2013).

Menurut J. Banyte et al (2021), factorfaktor yang menyebabkan keterlibatan konsumen antara lain : kemudahan akses informasi, penciptaan hubungan, identitas sosial atau bentuk aktualisasi diri, sebagai bentuk bantuan kepada orang lain, kenyamanan, kontribusi, dan status.

Di samping itu, menurut Reitz (2012) dalam J. Banytė et al (2021) atribut seperti kualitas informasi, perasaan senang dan interaktivitas merupakan faktor penting yang dapat mempengaruhi keterlibatan konsumen dalam lingkungan virtual (gamifikasi). Keterlibatan konsumen dalam ruang virtual dapat dipahami dengan menganalisis pengalaman konsumen di dalam ruang virtual tersebut (Banytè, Kuvykaite, \& Tarutè, 2021).

Keterlibatan konsumen dalam gamifikasi dapat dibentuk antara lain dengan membuat suatu gamifikasi yang sifatnya menyenangkan dan membuat konsumen terlibat dalam sebuah permainan online secara berulang. Bahkan akan merasa ada yang kurang apabila melewatkan waktu untuk bermain online game. Keberhasilan permainan online dalam mengundang akses secara berulang tidak hanya karena manfaat rasional yang akan diperoleh seseorang ketika bermain, tetapi juga kesenangan dan keterlibatan emosional yang mendorong rasa penasaran untuk mengeksplorasi apa yang akan diperoleh ketika mencapai level yang lebih tinggi, atau menggunakan fitur lainnya dalam permainan tersebut (Piligrimienè, 2021; Banytė, Kuvykaitė, \& Tarutè, 2021).

Dalam sebuah marketplace, gamifikasi harus mengakomodasi ketertarikan yang berbeda dari bermacam-macam segmentasi pasar. Secara umum, sebuah permainan online memiliki karakteristik yang berbeda. Ada permainan yang melibatkan pemain dalam waktu lama dalam satu kali akses permainan tersebut. Ada pula yang membutuhkan waktu singkat untuk mencapai level tertentu, tetapi terus berlanjut ke level yang lebih tinggi sehingga membuat pemain penasaran dan tanpa disadari terus mengikuti proses permainan. Pada sebuah marketplace, karena terdapat kepentingan lain, yaitu konsumen juga memperhatikan promosi yang diberikan, maka di sebuah marketplace juga disediakan permainan yang membutuhkan waktu sebentar, tetapi berulang untuk memperoleh pencapaian tertetntu (Piligrimienè, 2021). Seseorang yang mulai bosan dengan suatu permainan di sebuah marketplace, akan terlihat dari frekuensi atau intensitasnya bermain di situs tersebut. Oleh sebab itu, 
perusahaan perlu melakukan inovasi permainan secara terus menerus.

\section{Keinginan Mengunjungi Ulang}

Minat adalah kecenderungan aktivitas yang akan atau tidak akan dilakukan oleh seorang individu (Yunus, 2014). Minat juga berujuk pada besarnya keinginan individu untuk mencapai tujuannya. Minat merupakan salah satu aspek psikis dari manusia yang mempunyai kecenderungan untuk merasa senang atau memberikan perhatian yang lebih besar kepada objek tersebut yang dapat mendorong motivasi untuk mencapai tujuan (Kusuma \& Susilowati, 2009).

Menurut Fusilier dan Durlabhiji seperti dikutip oleh Yunus (2014) terdapat 2 hal yang dapat mendukung minat menggunakan gamifikasi. Pertama, adalah pengguna tertarik menggunakan aplikasi setelah mencobanya. Kedua, adalah adanya harapan pengguna untuk menggunakan ulang aplikasi tersebut.

Zeitaml, et al seperto dikutip oleh Ibzan, Balarabe \& Jakada (2016) mengemukakan bahwa repurchase intention dapat diidentifikasi menjadi keinginan untuk membeli kembali (repurchase) dan keinginan untuk menyebarkan word of mouth positif serta memberikan rekomendasi. Kotler \& Keller (2016) mengatakan bahwa post-purchase action dari seorang konsumen yang puas adalah melakukan pembelian ualng dan cenderung untuk mengatakan hal-hal baik mengenai merek atau produk tersebut kepada orang lain.

Pada penelitian ini minat mengunjungi ulang diukur berdasarkan indicator dari minat beli ulang seperti yang dikemukakan oleh Ferdinand (2002), yaitu :

1. Minat Transaksional : Perilaku seseorang yang ingin membeli kembali sebuah produk.
2. Minat Referensial : Perilaku seseorang untuk mereferensikan atau merekomendasikan produk kepada orang lain.

3. Minat Preferensial : Perilaku seseorang yang memiliki preferensi utama pada suatu produk. Preferensi ini hanya dapat diganti apabila terjadi sesuatu dengan produk preferensinya.

4. Minat Eksploratif : Perilaku seseorang yang selalu mencari informasi mengenai produk yang diminatinya dan mencari informasi untuk mendukung sifat-sifat positif dari produk tersebut.

\section{METODOLOGI}

Penelitian ini menggunakan metode penelitian kuantitatif yang mana menggunakan teknik pengambilan sample purposive sampling, analisis data bersifat kuantitatif dengan menggunakan alat bantu statistik untuk menguji hipotesis yang telah ditetapkan (Sugiyono, 2016).

Dalam penelitian ini, pengumpulan dan analisis studi pustaka dilakukan untuk memperoleh dasar hubungan secara teoritis dan mempelajari dimensi dan indikator yang digunakan untuk mengukur variabel gamifikasi dan minat mengunjungi ulang pada penelitian terdahulu. Disamping itu dilakukan observasi secara menyeluruh pada objek penelitian, yaitu Marketplace X di Indonesia untuk melihat elemenelemen gamifikasi yang disediakan. Dari semua data yang diperoleh, menjadi dasar untuk membangun dimensi dan indikator yang akan digunakan sebagai alat pada penelitian ini.

\section{Operasionalisasi Variabel}

Gamifikasi pada Marketplace X akan diukur dalam 2 aspek, yaitu manfaat yang memotivasi konsumen untuk bermain dan pengalaman dalam gamifikasi di marketplace tersebut. Untuk Motivasi dijabarkan ke dalam beberapa macam, yaitu: 
Tabel 1. Operasionalisasi Variabel

\begin{tabular}{|c|c|c|c|}
\hline Variabel & Dimensi & Indikator & Sumber \\
\hline \multirow[b]{2}{*}{ Gamifikasi (2) } & motivasi & $\begin{array}{l}\text { 1.Perolehan koin yang dapat digunakan berbelanja di Marketplace X } \\
\text { 2.Perolehan cashback di Marketplace X } \\
\text { 3.Penukaran point dengan voucher di Marketplace X } \\
\text { 4.Pencapaian level tertentu di Marketplace X }\end{array}$ & (Piligrimiené, 2021) \\
\hline & $\begin{array}{l}\text { Keterlibat } \\
\text { an }\end{array}$ & $\begin{array}{l}\text { 1. Keinginan mencoba semua permainan di Marketplace X } \\
\text { 2. Waktu tanpa terasa berlalu ketika bermain games di marketplace X } \\
\text { 3.Bersemangat ketika bermain games di Marketplace X } \\
\text { 4.Merasa terpikat dengan pemainan di Marketplace X } \\
\text { 5.Terhibur ketika bermain games di Marketplace X } \\
\text { 6. Games di Marketplace X mudah dimainkan } \\
\text { 7.Tampilan games di Marketplace X }\end{array}$ & (Piligrimienè, 2021) \\
\hline \multirow[t]{4}{*}{$\begin{array}{l}\text { Minat } \\
\text { Mengunjungi } \\
\text { Ulang }\end{array}$} & $\begin{array}{l}\text { Minat } \\
\text { Transaksi } \\
\text { onal }\end{array}$ & $\begin{array}{l}\text { 1.Saya tertarik untuk terus mengunjungi Marketplace X di waktu yang } \\
\text { akan datang } \\
\text { 2.Games yang ada di Marketplace X memunculkan minat saya untuk } \\
\text { mengunjungi ulang Marketplace X. }\end{array}$ & \multirow[t]{4}{*}{ (Ferdinand, 2002) } \\
\hline & $\begin{array}{l}\text { Minat } \\
\text { Referensia } \\
1\end{array}$ & $\begin{array}{l}\text { 1. Saya berminat untuk merekomendasikan orang-orang/teman untuk } \\
\text { mengunjungi Marketplace X } \\
\text { 2. Saya berminat untuk mengajak teman/orang lain untuk memainkan } \\
\text { games yang tersedia di Marketplace X }\end{array}$ & \\
\hline & $\begin{array}{l}\text { Minat } \\
\text { Preferensi } \\
\text { al }\end{array}$ & $\begin{array}{l}\text { 1.Saya lebih menyukai bermain games yang ada di Marketplace } \mathrm{X} \\
\text { dibanding games yang ada di e-commerce lain. }\end{array}$ & \\
\hline & $\begin{array}{l}\text { Minat } \\
\text { eksploratif }\end{array}$ & $\begin{array}{l}\text { 1. Saya tertarik untuk mencari tau teman/orang lain yang saya kenal } \\
\text { yang juga bermain games di Marketplace X } \\
\text { 2. Saya tertarik untuk mencoba games baru yang ada di Marketplace X. }\end{array}$ & \\
\hline
\end{tabular}
Sumber : Pengolahan Data

\section{Rancangan Penelitian}

Populasi penelitian ini adalah konsumen marketplace X di Kota Bandung. Dikarenakan jumlah populasi yang cukup banyak (tidak terhingga) digunakan perhitungan seperti berikut ini :

$$
n=\frac{\left(\frac{z \alpha}{2}\right)^{2} p \cdot q}{d^{2}}
$$

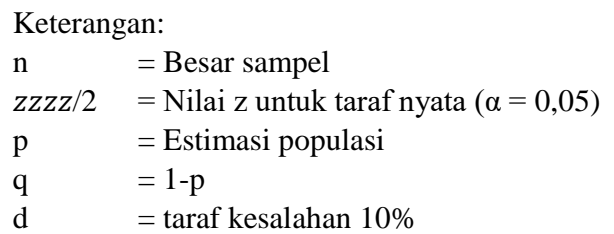

Bila $\alpha=5 \%$ dan $\mathrm{d}=10 \%$ dengan asumsi $\mathrm{p}$ $=0,5$ dan populasi tidak terhingga maka $\mathrm{n}$ (jumlah sampel) yang dibutuhkan adalah 96,04. Dalam penelitian ini dibulatkan menjadi 100 sampel untuk mewakili seluruh populasi.

Teknik pengambilan sampel menggunakan teknik non probability sampling yaitu Purposive Sampling. Pemilihan teknik ini didasari pertimbangan bahwa responden yang menjadi subjek penelitian adalah konsumen yang sudah pernah memainkan games di layanan Marketplace X. Pengambilan sampel menggunakan metode survey dengan membagikan kuisioner kepada konsumen yang pernah memainkan games Marketplace X.

Data yang terkumpul akan diolah dengan uji regresi linear sederhana untuk mengetahui pengaruh gamifikasi di Marketplace $X$ terhadap keinginan untuk mengunjungi ulang seperti ditunjukkan oleh gambar 1 berikut ini :

\begin{tabular}{|c|c|}
\hline & \\
\hline \multirow{5}{*}{$\begin{array}{l}\text { Gamifikasi } \\
\text { 1. Motivasi } \\
\text { 2. Keterlibatan } \\
\text { konsumen }\end{array}$} & Mengunjungi Ulang \\
\hline & 1. Minat \\
\hline & Transaksional \\
\hline & 2. Minat Referensial \\
\hline & $\begin{array}{l}\text { 3. Minat Preferensial } \\
\text { 4. Minat Eksploratif }\end{array}$ \\
\hline
\end{tabular}

Gambar 1. Model Penelitian

Adapun rumus regresi linear yang digunakan adalah sebagai berikut (Sugiyono, 2016) :

$$
Y=a+b X
$$

Keterangan:

Y: subjek nilai dalam variabel terikat yang diprediksikan

a : konstanta atau bila $\mathrm{X}=0$

$\mathrm{b}$ : koefisien regresi

$\mathrm{X}$ : subjek pada variabel bebas yang mempunyai nilai tertentu 
Koefisien determinasi digunakan untuk menghitung besarnya pengaruh variabel bebas terhadap variabel terikat. Dalam SPSS, untuk satu variabel bebas digunakan $\mathrm{R}$ Square, tetapi jika terdapat dua atau lebih variabel bebas, maka digunakan Adjusted $\mathrm{R}$ Square. Rumus yang digunakan untuk menghitung koefisien determinasi adalah sebagai berikut (Sarwono, 2012):

$$
K_{d}=r_{s}^{2} \times 100 \%
$$

Keterangan:

$\mathrm{Kd}=$ Koefisien Determinasi

rs2 $=$ Hasil Korelasi

Di samping itu, uji hipotesis dilakukan dengan menggunakan Uji T. Hipotesis merupakan jawaban sementara terhadap rumusan masalah penelitian, dimana rumusan masalah penelitian telah dinyatakan dalam bentuk kalimat pertanyaan (Sugiyono, 2016). Uji Hipotesis Parsial (uji t) dilakukan untuk membuktikan rumusan masalah "apakah gamifikasi berpengaruh terhadap minat mengunjungi ulang". Adapun hipotesis pada penelitian ini adalah sebagai berikut:

Ho: Gamifikasi tidak mempengaruhi Minat Mengunjungi Ulang Markeplace X

Ha:Gamifikasi mempengaruhi Minat Mengunjungi Ulang Markeplace X

$\mathrm{H} 0$ diterima jika $-\mathrm{t}$ tabel $\leq \mathrm{t}$ hitung $\leq \mathrm{t}$ tabel.

Ha ditolak jika $-\mathrm{t}$ hitung $<\mathrm{t}$ tabel atau $\mathrm{t}$ hitung $>\mathrm{t}$ tabel

Tingkat signifikansi yang digunakan $(\alpha)$ sebesar 5\% dengan derajat kepercayaan sebesar 95\% diperoleh nilai t tabel yaitu sebesar 1,98

Tabel 2. Profil Responden

\begin{tabular}{|c|c|c|}
\hline Variabel & Kategori & Persentase (\%) \\
\hline \multirow{3}{*}{$\begin{array}{l}\text { Jenis } \\
\text { Kelamin }\end{array}$} & Laki-laki & 25 \\
\hline & Perempuan & 75 \\
\hline & Total & 100 \\
\hline \multirow[t]{5}{*}{ Usia } & $16-19$ Tahun & 8 \\
\hline & $20-25$ Tahun & 55 \\
\hline & $26-30$ Tahun & 28 \\
\hline & Lebih dari 30 Tahun & 9 \\
\hline & Total & 100 \\
\hline \multirow{5}{*}{$\begin{array}{l}\text { Frekuensi } \\
\text { bermain per } \\
\text { Hari }\end{array}$} & Tidak Selalu & 42 \\
\hline & $1-3$ kali & 36 \\
\hline & 4-5 kali & 16 \\
\hline & Lebih dari 5 kali & 6 \\
\hline & Total & 100 \\
\hline \multirow[t]{5}{*}{ Pekerjaan } & Mahasiswa/Pelajar & 52 \\
\hline & Karyawan & 35 \\
\hline & Wirausaha & 5 \\
\hline & Bapak/Ibu Rumah Tangga & 8 \\
\hline & Total & 100 \\
\hline \multirow{12}{*}{$\begin{array}{l}\text { Game ang } \\
\text { perna } \\
\text { dimainkan }\end{array}$} & X Lucky Prize & 91 \\
\hline & X Tangkap & 28 \\
\hline & X Lempar & 49 \\
\hline & $\mathrm{X}$ Potong & 33 \\
\hline & X Tanam & 28 \\
\hline & X Serba 10ribu & 52 \\
\hline & Share \& Dapatkan & 16 \\
\hline & Goyang X & 83 \\
\hline & Mission X & 26 \\
\hline & X Tebak Juara & 15 \\
\hline & $\mathrm{X}$ Vote Pemain Favorite & 15 \\
\hline & X Klub Favorit & 14 \\
\hline
\end{tabular}




\section{PEMBAHASAN DAN HASIL PENELITIAN}

\section{Profil Responden}

Penyebaran kuisioner dilakukan kepada 100 orang responden yang pernah memainkan gamifikasi Marketplace X dan berdomisili di Kota Bandung. Responden didominasi oleh responden berjenis kelamin wanita sebanyak 75 orang $(75 \%)$. Pada tabel 2, dapat dilihat bahwa sebanyak 91\% responden bermain $\mathrm{X}$ lucky price, $83 \%$ goyang $\mathrm{X}$ lempar, 52\% Serba 10 ribu, dan $49 \%$ X Lempar Potong. Permainan seperti $\mathrm{X}$ lucky price merupakan sebuah permainan dimana pengguna hanya tinggal membuka sebuah telor untuk melihat hadiah yang diperolehnya. Dari contoh ini dapat dilihat bahwa permainan yang dipilih oleh mayoritas responden perempuan tersebut cenderung tidak kompetitif. Hal ini sejalan dengan hal yang dikemukakan oleh Hartamann \& Klimmt (2006) dalam Taruli, Chan, \& Tresna (2020) bahwa jenis kelamin mempengaruhi preferensi permainan yang digunakan yang mana wanita kurang tertarik pada permainan online yang bersifat kompetitif namun lebih tertarik pada permainan yang melibatkan hubungan jangka panjang serta mudah untuk digunakan.

Jika melihat pada komponen usia, mayoritas responden yang mengisi kuisioner berada pada rentang usia $20-25$ tahun yang mana sejalan dengan komponen pekerjaan yang mayoritas diisi oleh mereka yang bekerja sebagai mahasiswa atau pelajar. Di samping itu, mayoritas responden yang berada di bawah 30 tahun, menunjukkan juga kesesuaian dengan penelitian yang dilakukan oleh Taruli, Chan, \& Tresna (2020) di mana gamifikasi di marketplace umumnya menyasar generasi milenial.

\section{Uji Validitas}

Uji validitas ditujukan untuk mengukur valid atau tidaknya suatu instrumen pernyataan penelitian. Uji validitas dilakukan kepada 40 responden, dengan menggunakan program SPSS 17.00 yang akan diukur dengan pearson product moment. Adapun item pertanyaan yang diuji sebanyak 18 item yang terdiri dari pertanyaan mengenai variable gamifikasi $(\mathrm{X})$ sebanyak 11 buah dan variabel minat mengunjungi ulang $(\mathrm{Y})$ sebanyak 7 buah. Agar instrument pernyataan penelitian bisa dikatakan valid maka nilai r-hitung > nilai r-tabel. Pada tabel distribusi, nilai r-tabel dengan jumlah $\mathrm{N}=40$ pada taraf signifikansi $5 \%$ diketahui sebesar 0,312. Maka nilai r-hitung pada seluruh instrument penelitian harus lebih besar dari 0,312 (>0,312). Dari pengujian validitas yang dilakukan maka didapatkan hasil sebagai berikut

Tabel 3. Hasil Uji Validitas

\begin{tabular}{|c|c|c|c|c|}
\hline Variabel & $\begin{array}{c}\text { NomorI } \\
\text { tem }\end{array}$ & $\begin{array}{c}\text { r- } \\
\text { hitun } \\
\mathbf{g}\end{array}$ & $\begin{array}{c}\text { r- } \\
\text { tabel }\end{array}$ & $\begin{array}{c}\text { Keterang } \\
\text { an }\end{array}$ \\
\hline \multirow{11}{*}{ Gamifikasi } & 1 & 0,734 & 0,312 & Valid \\
\hline & 2 & 0,561 & 0,312 & Valid \\
\hline & 3 & 0,557 & 0,312 & Valid \\
\hline & 4 & 0,761 & 0,312 & Valid \\
\hline & 5 & 0,739 & 0,312 & Valid \\
\hline & 6 & 0,783 & 0,312 & Valid \\
\hline & 7 & 0,806 & 0,312 & Valid \\
\hline & 8 & 0,790 & 0,312 & Valid \\
\hline & 9 & 0,738 & 0,312 & Valid \\
\hline & 10 & 0,592 & 0,312 & Valid \\
\hline & 11 & 0,474 & 0,312 & Valid \\
\hline \multirow{7}{*}{$\begin{array}{c}\text { Minat } \\
\text { Mengunjungi } \\
\text { Ulang }\end{array}$} & 12 & 0,609 & 0,312 & Valid \\
\hline & 13 & 0,766 & 0,312 & Valid \\
\hline & 14 & 0,804 & 0,312 & Valid \\
\hline & 15 & 0,559 & 0,312 & Valid \\
\hline & 16 & 0,855 & 0,312 & Valid \\
\hline & 17 & 0,779 & 0,312 & Valid \\
\hline & 18 & 0,849 & 0,312 & Valid \\
\hline
\end{tabular}

Tabel 3 menunjukkan bahwa instrument penelitian ini valid. Hal ini dapat dilihat dari nilai r-hitung lebih besar dari r-tabel $(0,312)$ sehingga seluruh instrument dapat digunakan sebagai alat pengumpul data.

\section{Uji Reliabilitas}

Langkah selanjutnya setelah melakukan uji validitas adalah uji reliabilitas. Uji Reliabilitas dilakukan untuk menguji keandalan dari alat ukur atau kuesioner yang digunakan. Uji reliabilitas menggunakan sample sejumlah 40 responden dengan menggunakan metode uji statistik alpha cronbach's dengan bantuan program SPSS 17.00. Adapun ketentuan uji reliabilitas :

1. Jika hasil reliabilitas menunjukan alpha $<0,6$ maka instrumen tersebut tidak layak untuk digunakan,

2. Jika alpha menunjukkan nilai > 0,7 maka instrument dinyatakan layak untuk digunakan. 
3. Jika alpha menunjukkan nilai $>0,8$ maka instrumen dikatakan baik dan layak untuk digunakan.

Tabel 4. Hasil Uji Reliabilitas

\begin{tabular}{|l|c|c|}
\hline Variabel & $\begin{array}{c}\text { Cronbach's } \\
\text { Alpha }\end{array}$ & N of Items \\
\hline Gamifikasi (X) & 0,888 & 11 \\
\hline $\begin{array}{l}\text { Minat } \\
\text { Mengunjungi } \\
\text { Ulang (Y) }\end{array}$ & 0,873 & 7 \\
\hline
\end{tabular}

Hasil uji reliabilitas menunjukkan variabel gamifikasi (X) sebesar 0,873 yang berarti r11>0.8. Hal ini menunjukkan bahwa alat ukur (instrument) baik dan dapat dinyatakan reliabel dan konsisten (Pratomo, 2018).

Hasil uji reliabilitas menunjukkan variabel minat mengunjungi ulang $(\mathrm{Y})$ sebesar 0,873 yang berarti r11>0.8. Hal ini menunjukkan bahwa alat ukur (instrument) baik dan dapat dinyatakan reliabel dan konsisten (Pratomo, 2018). Dapat disimpulkan bahwa keandalan seluruh instrument penelitian memenuhi syarat.

\section{Uji Normalitas}

Uji normalitas digunakan untuk melihat apakah data residual terdistribusi normal atau tidak. Uji ini perlu dilakukan agar model regresi tidak bias dan pengujian dapat dipercaya. Pada penelitian ini, uji normalitas menggunakan uji onesample Kolmogorov-Smirnov. Pengujian ini digunakan untuk melihat apakah data terdistribusi normal, poisson, uniform atau exponential. Data terdistribusi normal apabila nilai signifikasi lebih dari 0,05 (Priyatno, 2014).

Tabel 5. Hasil Uji Normalitas

\begin{tabular}{|l|l|l|}
\hline & & $\begin{array}{l}\text { Unstandardized } \\
\text { Residual }\end{array}$ \\
\hline $\mathrm{N}$ & Mean & 100 \\
\hline $\begin{array}{l}\text { Normal } \\
\text { Parameters }\end{array}$ & 0.0000000 \\
\hline & Std.deviation & 2,01416972 \\
\hline $\begin{array}{l}\text { Most Extreme } \\
\text { Differences }\end{array}$ & Absolute & 0,82 \\
\hline & Positive & 0,55 \\
\hline $\begin{array}{l}\text { Kolmogorov- } \\
\text { Smirnov Z }\end{array}$ & Negative & $-0,82$ \\
\hline $\begin{array}{l}\text { Asymp. Sig. (2- } \\
\text { tailed) }\end{array}$ & & 0,822 \\
\hline
\end{tabular}

Berdasarkan tabel diatas, hasil pengujian menunjukan nilai signifikansi sebesar 0,509 dimana hasil tersebut lebih besar dari nilai minimum yaitu 0,05 . Oleh karena itu, dapat disimpulkan bahwa seluruh data terdistribusi normal.

\section{Uji Heterokedastisitas}

Uji heterokedastisitas bertujuan untuk menguji apakah dalam model regresi terjadi ketidaksamaan variasi dari residual suatu pengamatan ke pengamatan yang lain (Ghozali, 2013). Model regresi yang baik seharusnya adalah homokedastisitas dan/atau tidak terjadi heterokedastisitas.

Uji heterokedastisitas dilakukan dengan menggunakan metode scatterplot. Apabila tidak ada plot yang jelas dimana titik-titik menyebar diatas dan dibawah angka nol (0) pada sumbu Y, maka hal tersebut menunjukan terjadinya homokedastisitas atau tidak terjadi heterokedastisitas. Berikut ini adalah hasil pengujian heterokedastisitas dengan menggunakan SPSS 17.00:

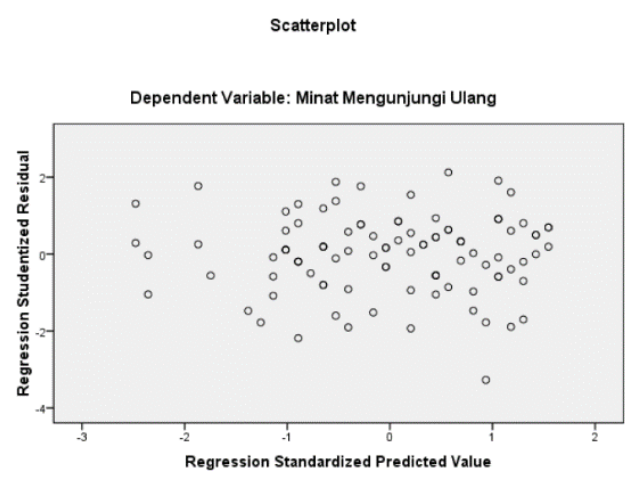

Gambar 2. Hasil Uji Heterogenitas

Berdasarkan gambar 2 diatas, hasil pengujian menunjukan bahwa titik-titik menyebar secara acak dan tersebar diatas dan dibawah angka 0 pada sumbu Y. Dengan demikian, dapat disimpulkan telah terjadi homokedastisitas atau tidak terjadi heterokedastisitas sehingga model regresi dapat digunakan untuk penelitian.

\section{Analisis Deskriptif}

Analisis deskriptif membahas tanggapan responden atas variabel gamifikasi (X) dan variabel minat mengunjungi ulang $(\mathrm{Y})$ dengan melakukan pengukuran berdasarkan indikator 
sebagai instrument pernyataan seperti yang diuraikan pada table 1 .

Survey dilakukan dengan menyebarkan kuisioner kepada 100 responden yang akan memberikan penilaian terhadap 18 pertanyaan yang berasal dari indikator penelitian (seperti pada table 1). Skala pengukuran menggunakan skala ordinal dari sangat setuju (poin 5) sampai sangat tidak setuju (poin 1). Hal ini digunakan untuk mempermudah menginterpretasi tanggapan responden terhadap variabel $\mathrm{X}$ dan $\mathrm{Y}$. Adapun perhitungan yang digunakan untuk mengkategorikan tanggapan tersebut akan mengacu pada kriteria rata-rata (mean) dengan cara sebagai berikut :

- Nilai Minimal $=$ bobot minimum $\mathrm{x}$ jumlah responden

- Nilai Maksimal $=$ bobot maksimum $\mathrm{x}$ jumlah responden

\section{- Jarak interval = Nilai Maksimal - Nilai Minimal Jumlah Kategori}

Selanjutnya nilai minimal, nilai maksimal, dan jarak interval harus dibagi dengan jumlah seluruh responden yaitu 100 untuk mengetahui nilai rata-ratanya. Rata-rata kriteria tanggapan responden pada penelitian ini adalah sebagai berikut :

Tabel 6. Rata-rata kriteria tanggapan responden

\begin{tabular}{|l|l|l|}
\hline No. & Nilai Rata-rata & Kriteria \\
\hline 1. & $1,00-1,80$ & Tidak Setuju \\
\hline 2. & $1,81-2,60$ & Kurang Setuju \\
\hline 3. & $2,61-3,40$ & Cukup Setuju \\
\hline 4. & $3,41-4,20$ & Setuju \\
\hline 5. & $4,21-5,00$ & Sangat Setuju \\
\hline
\end{tabular}

Tabel 7. Rekapitulasi Tanggapan Responden atas Variabel Gamifikasi dan Minat Mengunjungi Ulang

\begin{tabular}{|c|r|}
\hline Pernyataan & Rata-Rata \\
\hline Dimensi Motivasi & 3,66 \\
1. Perolehan koin yang dapat digunakan berbelanja di Marketplace X & 4,19 \\
2. Perolehan cashback dari bermain games di Marketplace X & 3,99 \\
3. Voucher yang diperoleh dari bermain games di Marketplace X & 3,35 \\
4. Pencapaian level tertentu di Marketplace X & 3,79 \\
\hline Rata-rata Dimensi Motivasi & \\
\hline Dimensi Keterlibatan & 3.73 \\
5. Mencoba semua permainan di Marketplace X & 3,60 \\
6. Waktu tanpa terasa berlalu ketika bermain games di marketplace X & 3,74 \\
7. Bersemangat ketika bermain games di Marketplace X & 3,54 \\
8. Merasa terpikat dengan pemainan di Marketplace X & 3,97 \\
9. Terhibur ketika bermain games di Marketplace X & 4,40 \\
10. Games di Marketplace X mudah dimainkan & 4,06 \\
11. Tampilan games di Marketplace X & 3,86 \\
\hline Rata-rata Dimensi Keterlibatan & 3,82 \\
\hline Rata-rata Variabel Gamifikasi & \\
\hline Minat Mengunjungi Ulang & 4,18 \\
12. Keinginan untuk mengunjungi kembali Marketplace X & 3,59 \\
13. Keinginan mengunjungi kembali untuk bermain games di Marketplace X & 4,11 \\
14. Keinginan untuk merekomendasikan Marketplace X & 3,43 \\
15. Keinginan untuk mengajak orang lain bermain games yang ada di Marketplace & \\
X & 3,57 \\
16. Lebih menyukai games yang ada di Marketplace X dibandingkan marketplace & \\
17. Keinginan mencari informasi mengenai siapa saja teman/kenalan yang juga & 3,21 \\
18. Keinginan untuk mencoba games baru yang disediakan oleh Marketplace X & \\
\hline Rata-rata Variabel Minat Mengunjungi Ulang & 3,78 \\
\hline
\end{tabular}

Berdasarkan tabel 7 dapat disimpulkan bahwa responden umumnya menilai variabel gamifikasi dan variabel minat mengunjungi ulang marketplace X pada kategori cukup setuju, setuju dan sangat setuju. Beberapa komponen yang dinilai responden cukup setuju, sebaiknya ditinjau ulang oleh Marketplace X agar marketplace X dapat memberikan gamifikasi yang sesuai ekspekstasi 
pengguna juga dapat mempengaruhi minat mengunjungi ulangnya.

Dimensi motivasi pada variabel gamifikasi (X) dengan nilai mean terendah adalah pernyataan no 4 yaitu "Pencapaian level tertentu di Marketplace X" yang merupakan bagian dari dimensi motivasi ekstrinsik. Nilai mean terendah ini masih masuk dalam kategori cukup setuju, di mana kondisi ini menunjukkan tanggapan netral responden. Hal ini menunjukkan bahwa pengguna ragu-ragu atas penting atau tidaknya level games di marketplace X. Hal ini juga menunjukkan bahwa karakteristik pengguna games di marketplace $\mathrm{X}$ berbeda dibandingkan pemain online game murni, dimana para pemain berlomba untuk memenangkan permainan agar mencapai level tertentu. Di samping itu, hal ini menjadi tantangan sendiri bagi perusahaan agar dapat meningkatkan ketertarikan pengguna bermain games untuk mencapai level tertentu. Hal ini dapat dilakukan dengan meningkatkan brand awareness atas gamifikasi yang disediakan dimana pengguna dapat merasa dan/atau memperoleh manfaat sosial atau pengakuan sosial ketika bermain games. Misalnya pengguna merasa "keren" saat bermain games tersebut, atau merasa unggul/ kompeten saat mencapai level tertentu, dan lain sebagainya. Adanya ketertarikan pengguna untuk mencapai level tertentu memperbesar kemungkinan pengguna untuk mengunjungi ulang marketplace $X$ tersebut (meningkatkan frekuensi mengunjungi ulang).

Di samping itu, rata-rata tertinggi dari dimensi motivasi adalah pernyataan no 2 yaitu "Perolehan cashback dari bermain games di Marketplace X" dengan nilai 4,19 yang masuk dalam kategori "setuju". Hasil tanggapan ini menunjukkan bahwa motivasi yang mempengaruhi seseorang bermain games di marketplace $\mathrm{X}$ adalah untuk mengejar cashback yang dapat digunakan untuk berbelanja di marketplace X. Responden lebih menyukai cashback dibandingkan tawaran berbelanja lainnya seperti : voucher belanja, koin, dan lain sebagainya. Penggunaan cashback dapat dimanfaatkan perusahaan sebagai daya tarik agar pengguna mau memainkan games di marketplace $\mathrm{X}$.

Sedangkan rata-rata tertinggi pada variabel gamifikasi dengan nilai 4,40 ditunjukkan oleh tanggapan responden atas pernyataan no 10 yaitu “Games di Marketplace X mudah dimainkan" yang merupakan indikator dari dimensi keterlibatan. Pernyataan ini merupakan instrument satu-satunya yang masuk ke dalam kategori sangat setuju. Hal ini menunjukkan keunggulan dari gamifikasi marketplace $\mathrm{X}$ yang mudah untuk digunakan, tidak membutuhkan waktu lama untuk mepelajari permianan yang disediakan oleh marketplace $\mathrm{X}$. Hal ini juga menunjukkan bahwa tekanan bermain game di marketplace $X$ rendah, berbeda dengan games online umumnya seperti PUBG, MBLL dan lain sebagainya.

Rata-rata terendah dimensi keterlibatan adalah pernyataan 8 dengan skor 3,54 yang termasuk dalam kategori "Setuju". Pernyataan 8 yaitu "Merasa terpikat dengan pemainan di Marketplace X". Dari penyataan tersebut dapat disimpulkan bahwa pengguna games merasa puas dengan games yang disediakan oleh marketplace $\mathrm{X}$. Hal ini juga dapat ditingkatkan lagi dengan menyediakan games yang menarik atau unik, berbeda dengan marketplace lainnya.

Berdasarkan hasil pengolahan data untuk variabel gamifikasi $(\mathrm{X})$ dapat dilihat bahwa nilai rata-rata total untuk dimensi motivasi sebesar 3,79 dan dimensi keterlibatan sebesar 3,86, sedangkan rata-rata total untuk variabel gamifikasi adalah sebesar 3,83. Dari hasil tersebut dapat disimpulkan bahwa gamifikasi yang disediakan oleh marketplace $\mathrm{X}$ dinilai baik oleh responden yang mana rata-rata keterlibatan responden sebesar 3,86. Sedangkan gamifikasi marketplace $\mathrm{X}$ dinilai mampu memotivasi dengan baik dengan nilai ratarata 3,79 menurut responden. Dari hasil responden dapat disimpulkan bahwa permainan yang disediakan marketplace $\mathrm{X}$ menarik dan menyenangkan, tetapi tidak menyerap banyak perhatian dan waktu supaya masih ada ruang untuk mengekspos usaha promosi.

Selain itu, berdasarkan hasil analisis deskriptif pada variabel minat mengunjungi ulang (Y) yaitu minat mengunjungi ulang, diketahui bahwa nilai mean terendah sebesar 3,21 yang merupakan pernyataan "keinginan mencari informasi mengenai siapa saja teman/kenalan yang juga bermain games di Marketplace X". Hal ini menunjukan bahwa responden cenderung bermain games di marketplace $\mathrm{X}$ secara individu yang tidak membutuhkan pihak lain untuk bermain bersama. Hal ini sesuai dengan data yang ditunjukkan pada tabel 2 dimana mayoritas responden adalah wanita 
yang umumnya lebih menyukai permainan yang mana tidak ada kompetisi di dalamnya.

Variabel minat mengunjungi ulang (Y) dengan nilai rata-rata tertinggi sebesar 4,18 adalah pernyataan nomor 12 yaitu "Keinginan untuk mengunjungi kembali Marketplace X", termasuk pada kriteria "setuju". Dapat disimpulkan bahwa responden umumnya memiliki niat untuk mengunjungi ulang marketplace $X$, namun pernyataan ini terbatas karena belum dapat dikategorikan apakah niat mengunjungi ulang tersebut dipengaruhi oleh games atau tidak.

Pengelompokkan instrument penelitian berdasarkan kategori rata-rata tanggapan responden dapat dilihat pada tabel 8 . Data yang ditampilkan di tabel 8 menunjukkan bahwa mayoritas responden setuju dengan gamifikasi yang ditawarkan oleh Marketplace X dan umumya responden setuju untuk mengunjungi ulang marketplace X. Hal ini dilihat dari banyaknya pertanyaan yang dinilai "setuju" oleh responden.

Tabel 8. Pengelompokkan Pernyataan berdasarkan Kriteria Rata-rata Tanggapan

\begin{tabular}{|l|l|l|}
\hline No. & Kriteria & Pernyataan \\
\hline 3. & Cukup Setuju & 4,17 \\
\hline 4. & Setuju & $1,2,3,5,6,7,8,11,12,13,14,15,16,18$ \\
\hline 5. & Sangat Setuju & 10 \\
\hline
\end{tabular}

\section{Uji Korelasi}

Uji korelasi dilakukan untuk mengetahui seberapa kuat hubungan antara variabel Gamifikasi (X) dan Minat Mengunjungi Ulang (Y). Uji Korelasi dilakukan dengan menggunakan metode analisis korelasi Pearson Product Moment dengan bantuan program SPSS 17.00.

Berikut adalah hasil koefisien korelasi mengenai hubungan antara variabel Gamifikasi (X) dan Minat Mengunjungi Ulang (Y) :

Tabel 9. Hasil Uji Korelasi

\begin{tabular}{|c|c|c|c|}
\hline & & Gamifikasi & $\begin{array}{c}\text { Minat } \\
\text { Mengunjungi } \\
\text { Ulang }\end{array}$ \\
\hline \multirow[t]{3}{*}{ Gamifikasi } & $\begin{array}{l}\text { Pearson } \\
\text { Correlation }\end{array}$ & 1 & $0,928 * *$ \\
\hline & $\begin{array}{l}\text { Sig. } \\
\text { tailed })\end{array}$ & & 0,000 \\
\hline & $\mathrm{N}$ & 100 & 100 \\
\hline \multirow{3}{*}{$\begin{array}{l}\text { Minat } \\
\text { Mengunjungi } \\
\text { Ulang }\end{array}$} & $\begin{array}{l}\text { Pearson } \\
\text { Correlation }\end{array}$ & $0,928 * *$ & 1 \\
\hline & $\begin{array}{l}\text { Sig. } \\
\text { tailed) }\end{array}$ & 0,000 & \\
\hline & $\mathrm{N}$ & 100 & 100 \\
\hline
\end{tabular}

Nilai $r$ table $(\alpha=5 \%, n=100)$ adalah 0,195 . Sedangkan nilai r-hitung (dapat dilihat pada tabel 9) sebesar 0,928 . Hal ini menunjukkan bahwa $r-$ hitung > r-tabel yang berarti terdapat hubungan antara variabel gamifikasi (X) dan minat mengunjungi ulang (Y).

Di samping itu, bila mengacu berdasarkan nilai signifikansi sig. (2-tailed) sebesar 0,000, dapat disimpulkan bahwa $0,000<0,05(\alpha)$ yang berarti bahwa terdapat hubungan yang signifikan antara variabel gamifikasi (X) dan minat mengunjungi ulang $(\mathrm{Y})$.

\section{Analisis Regresi Linear Sederhana}

Tabel 10. Hasil Uji Regresi Linear Sederhana

\begin{tabular}{|c|c|c|c|c|c|}
\hline & \multicolumn{2}{|c|}{$\begin{array}{c}\text { Unstandardiz } \\
\text { ed } \\
\text { Coefficients }\end{array}$} & $\begin{array}{c}\text { Standardiz } \\
\text { ed } \\
\text { Coefficient }\end{array}$ & $\mathrm{t}$ & Sig. \\
\hline Model & B & $\begin{array}{c}\text { Std. } \\
\text { Error }\end{array}$ & Beta & & \\
\hline $\begin{array}{c}\text { (Constant } \\
\text { ) }\end{array}$ & $-\overline{0}, 017$ & 1,069 & & $\overline{0}-016$ & $\begin{array}{l}0,98 \\
7\end{array}$ \\
\hline $\begin{array}{c}\text { Gamifika } \\
\text { si }\end{array}$ & 0,612 & 0,025 & 0,928 & $\begin{array}{l}24,65 \\
7\end{array}$ & $\begin{array}{l}0,00 \\
0\end{array}$ \\
\hline
\end{tabular}

Hasil analisis regresi linear sederhana pada tabel 10 menghasilkan persamaan seperti berikut ini :

$$
Y=-0,017+0,612 X
$$

Komponen b $(0,612)$ pada persamaan tersebut menunjukkan apabila variabel gamifikasi (X) meningkat sebesar 1 satuan, maka akan meningkatkan variabel minat mengunjungi ulang (Y) sebesar 0,612.

\section{Analisis Koefisien Determinasi}

Koefisien Determinasi digunakan untuk menghitung besarnya pengaruh variabel independen terhadap variabel dependen. Dalam SPSS, untuk satu variabel independen menggunakan R Square, tetapi jika terdapat dua atau lebih variabel independen maka menggunakan Adjusted R Square.

Tabel 11. Analisis Koefisien Determinasi

\begin{tabular}{|c|c|c|c|c|}
\hline Model & R & R Square & $\begin{array}{c}\text { Adjusted } \\
\text { R Square }\end{array}$ & $\begin{array}{c}\text { Std. Error } \\
\text { of The } \\
\text { Estimate }\end{array}$ \\
\hline 1 & $0,928^{*}$ & 0,861 & 0,860 & 2,02442 \\
\hline
\end{tabular}


Koefisien determinasi sebesar 0.861 menunjukkan bahwa keinginan mengunjungi ulang dipengaruhi oleh gamifikasi sebesar $86.1 \%$ dan sisanya sebesar $13.9 \%$ dipengaruhi oleh hal lain yang tidak diukur dalam penelitian ini, seperti event khusus seperti harbolnas atau flash sale.

\section{Uji Hipotesis Parsial (Uji t)}

Rumusan hipotesis pada penelitian ini adalah sebagai berikut:

Ho : Gamifikasi tidak mempengaruhi Minat Mengunjungi Ulang Markeplace X

$\mathrm{Ha}$ :Gamifikasi mempengaruhi Minat Mengunjungi Ulang Markeplace X

Hasil uji t (dapat dilihat pada tabel 10) sebesar 24,480 lebih besar dari t-tabel sebesar $1,984(\alpha=5 \%)$ menunjukkan bahwa Ho ditolak dan Ha diterima. Hal ini berarti Gamifikasi (X) mempengaruhi minat mengujungi ulang $(\mathrm{Y})$.

\section{KESIMPULAN}

1. Gamifikasi Marketplace $\mathrm{X}$ yang dilihat dari dimensi motivasi dan keterlibatan konsumen terhadap penilaian dinilai cukup baik di mana rata-rata penilaian responden terhadap gamifikasi yakni sebesar 3,82 . Hal ini menarik untuk diteliti lebih lanjut, karena mayoritas responden pada penelitian ini adalah perempuan sehingga untuk ke depannya dapat dilakukan penelitian ulang (fokus pada jenis kelamin laki-laki) apakah memiliki pandangan yang sama terhadap gamifikasi yang ditawarkan oleh Marketplace X.

2. Hasil uji korelasi menunjukkan terdapat hubungan yang signifikan antara gamifikasi dan minat mengunjungi ulang. Adapun besar-nya pengaruh gamifikasi terhadap minat mengunjungi ulang adalah sebesar $86,1 \%$ yang dapat dikategorikan sangat berpengaruh. Hal ini merupakan sebuah kesempatan besar bagi Marketplace $\mathrm{X}$ untuk mengekspos usaha pemasaran lainnya kepada semakin banyak konsumen melalui gamifikasi. Oleh sebab itu, perusahaan perlu meningkatkan kualitas maupun jenis games yang dimilikinya.
3. Gamifikasi dapat mempengaruhi minat mengunjungi ulang dikarenakan gamifikasi dipengaruhi oleh dimensi motivasi konsumen seperti rasa penasaran, ingin mencoba serta ingin memperoleh imbalan dan dimensi keterlibatan seperti bentuk aktualisasi diri, kontribusi dan perasaan senang ketika bermain gamifikasi tersebut. Perolehan reward berupa cashback menjadi salah satu faktor yang paling mempengaruhi responden untuk mengunjungi ulang karena mereka memperoleh keuntungan saat bermain games yaitu cashback yang dapat digunakan untuk berbelanja di marketplace $\mathrm{X}$. Hal ini terlihat jelas pada nilai instrument penelitian yaitu pernyataan no 2 mengenai "Perolehan cashback dari bermain games di Marketplace X" sebesar 4,19 dalam kategori "setuju". Kondisi ini menunjukkan peluang bagi marketplace $\mathrm{X}$ untuk mengintegrasikan fitur gamifikasi dengan usaha pemasaran lainnya.

4. Bagi penelitian selanjutnya, dapat dilakukan penelitian mengenai faktor-faktor lain dalam gamifikasi di mana pada penelitian ini terbatas pada motivasi dan keterlibatan di dalam gamifikasi. Faktor-faktor lain yang dimaksud antara lain : elemen game, design game, informasi permainan dan lain sebagainya. Di samping itu, penelitian tentang minat mengunjungi ulang juga dapat dikaitkan dengan loyalitas, pembelian ulang, dan sebagainya.

\section{DAFTAR PUSTAKA}

Bovee, C. L., \& Thill, J. V. (2018). Business Communication Today. Edinburg: Pearson

Broer, J., \& Poeppelbuss, J. (2013). Gamification A New Phenomenon in Information Systems Research? in Hepu Deng and Craig Standing (ed.) ACIS 2013: Information systems: Transforming the Future: Proceedings of the 24th Australasian Conference on Information Systems, (pp. 1-13). Melbourne.

Deci, E., \& Ryan, R. (200). The "What" and "Why" of Goal Pursuits: Human Needs and the Self-Determination of Behavior. Psychological Inquiry 11, 227-268.

Dessart, L., Veloutsou, C., \& Morgan-Thomas, A. (2015). Consumer Engagement in Online 
Brand Communities: A Social Media Perspective. Journal of Product and Brand Management.

Deterding, S., Dixon, D., Khaled, R., \& Nacke, L. (2011). From Game Design Elements to Gamefulness: Defining Gamification. Proceedings of the 15th International Academic MindTrek Conference: Envisioning Future Media Environments, (pp. 9-15).

Erik M. Gregory, P. (2008). Understanding Video Gaming's engagement. Media psyschology Review Vol 1.

Ferdinand, A. (2002). Structural Equation Modelling dalam Penelitian Manajemen. Semarang: Fakultas Ekonomi UNDIP.

Ghozali, I. (2013). Aplikasi Analisis Multivariate dengan Program SPSS. Semarang: Badan Penerbit Universitas Diponegoro.

Hamari, J., Koivisto, J., \& Sarsa, H. (2014). Does Gamification Work? A Literature Review of Empirical Studies on Gamification. 47th Hawaii International Conference on System Science, (pp. 3025-3034).

Ibzan, E., Balarabe, F., \& Jakada, B. (2016). Consumer Satisfaction and Repurchase Intentions. Developing Country Studies.

iPrice Group Sdn Bhd. (2018). Peta E-Commerce Indonesia. Retrieved March 31, 2021, from iprice: https://iprice.co.id/insights/mapofecomme rce/

Kankanamge, N., Yigitcanlar, T., Goonetilleke, A., \& Kamruzzaman, M. (2020). How can gamification be incorporated into disaster emergency planning? A systematic review of the literature. International Journal of Disaster, 11(4), 481-506.

Kotler, P., \& Keller, K. L. (2016). Marketing Managemeny. Harlow: Pearson Education.

Marisa, F., Akhriza, T., Maukar, A., \& Wardhani, A. (2020). Gamifikasi (Gamification) Konsep dan Penerapan. JOINTECS (Journal of Information Technology and Computer Science), 5(3), 219-228. Retrieved from http://publishingwidyagama.ac.id/ejournalv2/index.php/jointecs

Marsudi, E. (2018). Pengaruh Gamifikasi Pada Aplikasi Tokopedia Terhadap Loyalitas Pelanggan.
Piligrimienè, Ž. (2021). Research Methodology of Gamification-Based Consumer Engagement in Value Creation in the Context of ICT Development. In R. Gatautis, J. Banytè, \& E. Vitkauskaite (Eds.), Gamification and Consumer Engagement Creating Value in Context of ICT Development (pp. 109-128). Springer. doi:https://doi.org/10.1007/978-3-03054205-4

Pratomo, A. (2018). Pengaruh Konsep Gamifikasi terhadap Tingkat Engagement. The Journal : Tourism and Hospitality Essentials Journal, 8(2), 63-74.

Sarwono, J. (2012). Metode Riset Skripsi: Pendekatan Kuantitatif Menggunakan Prosedur SPSS. Jakarta: Elex Media Komputindo.

Shang, S., \& Lin, K. (2013). An Understanding of the Impact of Gamification on Purchase Intention. AMCIS, 1-11.

Silviani, A., \& Cipto, R. (2018). Pengaruh Gamification, Social Media Marketing, Viral Marketing terhadap Minat Terus Menggunakan Storial.CO. Jurnal MADANI, 1(1), 1-20.

Sugiyono. (2016). Metode Penelitian Kuantitatif, Kualitatif, dan $R \& D$. Bandung: Alfabeta.

Xu, Y., Chen, Z., Peng, M.-P., \& Anser, M. (2020, Nov 23). Enhancing Consumer Online Purchase Intention Through Gamification in China: Perspective of Cognitive Evaluation Theory. Frontiers in Psychology. Retrieved from https://www.ncbi.nlm.nih.gov/pmc/article s/PMC7719710/\#B17

Yunus, M. (2014). Diffusion of Innovation, Consumer Attitudes and Intentions to Use Mobile Banking. Information and Knowledge Management.

Zichermann, G., \& Linder, J. (2010). Game-Based Marketing: Inspire Customer Loyalty Through Rewards, Challenges, and Contests. John Wiley \& Sons. 